\begin{tabular}{|l|l|l||}
\hline \multicolumn{2}{|c|}{ PublisherInfo } \\
\hline \hline PublisherName & $:$ & BioMed Central \\
\hline \hline PublisherLocation & $:$ & London \\
\hline \hline PublisherImprintName & $:$ & BioMed Central \\
\hline \hline
\end{tabular}

\title{
Role for IL-18 in rheumatoid arthritis
}

\begin{tabular}{|l|l|l||}
\hline \multicolumn{2}{|c|}{ ArticleInfo } \\
\hline \hline ArticleID & $:$ & 198 \\
\hline \hline ArticleDOI & $:$ & $10.1186 /$ ar-2000-66792 \\
\hline \hline ArticleCitationID & $:$ & 66792 \\
\hline \hline ArticleSequenceNumber & $:$ & 155 \\
\hline \hline ArticleCategory & $:$ & Paper Report \\
\hline \hline ArticleFirstPage & $:$ & 1 \\
\hline \hline ArticleLastPage & $:$ & 3 \\
\hline \hline & & RegistrationDate : 2000-3-17 \\
\hline ArticleHistory & $:$ & OnlineDate \\
\hline \hline ArticleCopyright & $:$ & Current Science Ltd2000-3-17 \\
\hline \hline ArticleGrants & $:$ & \\
\hline \hline ArticleContext & $:$ & 130753311 \\
\hline \hline
\end{tabular}


Aff1 Johns Hopkins University School of Medicine, USA

\section{Keywords}

Collagen-induced arthritis, IL-18, rheumatoid arthritis

\section{Context}

IL-18 is a novel cytokine with potent IFN-?-inducing activities that is involved in Th1 cell differentiation. Th1-mediated immune responses are known to play an important role in the pathogenesis of RA. However, the specific cytokine mediators and their relative roles in the initiation and maintenance of Th1 cell responses in RA synovium are not clear. To examine the expression of IL-18 and its receptor in RA synovial tissues and their potential functional effects within the synovial joint.

\section{Significant findings}

IL-18 and IL-18R were detected within RA synovial tissues. Addition of IL-18 to synovial cultures in vitro promoted the synthesis of GM-CSF, TNF-a, and NO. Levels of TNF-a were further augmented by the addition of IL-12 and/or IL-15. Furthermore, IL-18 together with IL-12 and IL-15 induced significant levels of IFN-? in these cultures. IL-18 induced TNF-a and IFN-? synthesis was suppressed by anti-inflammatory cytokines, IL-10 and TGF-?. IL-18 synthesis was induced by pro-inflammatory cytokines such as TNF-a and IL-1?. In vivo, administration of IL-18 to DBA/1 mice immunised with collagen II in incomplete Freund's adjuvant enhanced the development of an erosive inflammatory arthritis.

\section{Comments}

The study describes the expression of a pro-inflammatory cytokine, IL-18 and its receptor (IL-18R) in rheumatoid arthritis (RA) synovial tissues. The functional role of this cytokine was evaluated both in vitro (in a cell culture system) and in vivo (in an animal model of arthritis). In culture, IL-18 alone could promote the synthesis of granulocyte-macrophage colony-stimulating factor (GM-CSF), tumour necrosis factor alpha (TNF-a) and nitric oxide (NO). Furthermore, IL-18 together with IL-12 and IL-15 
augmented the synthesis of IFN-? and TNF-a. Monokines such as TNF-a and IL-1? induced IL-18 expression, suggesting a positive feedback loop that could potentially promote Th1 cell development. In vivo, IL-18 was found to facilitate the development of an erosive inflammatory arthritis in a collageninduced arthritis (CIA) mouse model. The data clearly document a pro-inflammatory role for IL-18 in the pathogenesis of arthritis.

\section{Methods}

Human IL-18 cDNA was cloned and expressed in bacteria, and the biological activity of the purified protein was determined by its ability to induce IFN-? synthesis in peripheral blood mononuclear cell culture. Monoclonal and sheep polyclonal anti-IL-18 specific antibodies were generated. Synovial membranes, synovial fluids and blood samples from RA and osteoarthritis patients were used for the study. The expression of IL-18 and its receptor was evaluated by RT-PCR, immunocytochemistry, FACS, and the functional effects of IL-18 on the synthesis of TNF-a and IFN-? were determined by an ELISA assay. IL-18 was administered (intraperitoneally) together with type II bovine collagen emulsified in incomplete Freund's adjuvant (intradermally) to DBA/1 mice to study the role of IL-18 in the pathogenesis of inflammatory arthritis.

\section{References}

1. Gracie JA, Forsey RJ, Chan WL, Gilmour A, Leung BP, Greer MR, Kennedy K, Carter R, Wei XQ, $\mathrm{Xu}$ DM, Field M, Foulis A, Liew FY, McInnes IB: A proinflammatory role for IL-18 in rheumatoid arthritis. J Clin Invest. 2000, 104: 1393-1401.

This PDF file was created after publication. 